\title{
Effect of the Nile Aquifer Lithological Characteristics on Groundwater Chemistry in Assiut Governorate, Egypt
}

\author{
Hussein Ali Saleem ${ }^{1,2^{*}}$, Mohamed R. El-Tahlawi', \\ Mohamed Abo-El Kassem', Gamal Y. Boghdady' \\ 1 Mining and Metallurgical Engineering Department, Faculty of Engineering, Assiut University, Assiut City, Egypt \\ 2 Mining Engineering Department, Faculty of Engineering, King Abdulaziz University, Saudi Arabia \\ * Corresponding author's e-mail: hseleem2002@yahoo.com
}

\begin{abstract}
The chemical composition of groundwater is affected by many features, including the impact caused by surrounding rocks. The Nile aquifer is surrounded by the calcareous structural plateau along the Assiut governorate on both sides. This paper aims at studying the effect of surrounding rocks on the chemical composition of groundwater in the Nile aquifer along the Assiut governorate. Fifty-five samples were taken from drinking water stations and irrigation wells in 2015, and then analyzed chemically in water and soil fertility laboratory located in the irrigation ministry in Assiut. Aquachem software package was used to determine the groundwater type and rock source deduction. Piper-trilinear diagram was plotted to show the hydrochemical facies. Furthermore, Gibbs diagram was applied to determine the correlation between water composition and aquifer lithological characteristics. The results revealed that nearly all of the groundwater samples drop in the water-rock interaction field. The results of rock source deduction show that the ratio of $\mathrm{Cl}$ to the sum of anions is less than 0.8 for all samples, concluding that the rock weathering is dominant. According to the criterion of TDS values, $78 \%$ of all the samples indicated that the carbonate weathering is prevalent; in turn, the ratio of $\mathrm{Mg}$ to Ca plus $\mathrm{Mg}$ shows that limestone-dolomite weathering is predominant. These results confirm that the calcareous structural plateau surrounding the Nile aquifer along the Assiut governorate has an effect on the groundwater chemistry by interacting between groundwater and limestone rocks which are the main component of the calcareous plateau.
\end{abstract}

Keywords: lithological characteristics, Nile aquifer, rock source deduction, Assiut.

\section{INTRODUCTION}

Groundwater is considered the second main source of drinkable water in the Assiut governorate, especially in the rural areas. Most areas of the governorate are supplied by drinking water through the groundwater extracted from the Nile aquifer. The groundwater plants are preferred to the surface water treatment plants due to their low cost of construction, and the short time of the construction phases (Aldar et al., 2011). The groundwater quality is considered as a function of its physicochemical properties and the geological factors (Bhargava and Killender, 1988). These geological factors affecting the groundwater quality depend on the soluble products of weathering, decomposition and related changes that occur in relation to time and place (Raghunath, 1987). The Nile aquifer is exposed to many chemical, physical and biological changes that occur due to the influence of internal and external factors. In this paper, the main focus was on the effect of calcareous structural plateau in the chemical analysis of groundwater. Dissolving and weathering of rocks may increase some chemical elements concentrations (Aldar et al., 2011). Clay minerals and sandstone can interact with leaked carbon dioxide existing in the soil to release cations like $\mathrm{Ca}$ and $\mathrm{Mg}$ (Freeze and Cherry, 1979). The weathering that occurred by the sodium- and 
potassium- bearing minerals can make $\mathrm{Ca}$ and $\mathrm{Na}$ dominant (Singh et al., 2011).

Assiut is one of the governorates in Egypt through which the Nile River passes. It is located between $26^{\circ} 47^{\prime} \mathrm{N}$. $-27^{\circ} 37^{\prime} \mathrm{N}$ latitudes and $30^{\circ} 37^{\prime}-31^{\circ} 34^{\prime} \mathrm{E}$ longitudes. It is bordered by El-Minia governorate to the north, and Sohag governorate to the south (Figure. 1). The Assiut governorate occupies $25,926 \mathrm{~km}^{2}$. The River Nile extends along the governorate for $125 \mathrm{~km}$. The width of the valley ranges between 16 and $60 \mathrm{~km}$ (Aldar et al., 2011).

River Nile splits the Assiut governorate into two portions. The Eastern part expands between El-Badary in the south and Manfalut in the north, while the Western part expands between ElGhanayim in the south and Dairut in the north. In wide-ranging, the earth surface at the ends of both sides descends towards the River Nile. The severe declination is the key feature of the borders (Dawoud and Ewea, 2009). Various dry drainage lines (Wadi) combined with the Assiut region such as Wadi El-Assiuti and Wadi El Ibrahimi in the central east, as well as Wadi Abu Shih in the south-east.

\section{GEOMORPHOLOGY}

There are four main geomorphologic features, including the young alluvial plain, the old alluvial terraces, the calcareous structural plateau, the desert hydrographic basins (Figure. 2) (Said, 1981).

These feature sites in the middle part around the River Nile, shape the cultivated land. The young alluvial plain is created from the silty-clay formations capping the graded sand and gravel unit. Some water streams run into this plain and irrigation channels as well (e.g., River Nile and El-Ebrahimia canal which goes into the middle of the plain).

The old alluvial terraces lie in the area between the foot slope of the Eocene scarps and the cultivated land. These terraces are classified as follows:

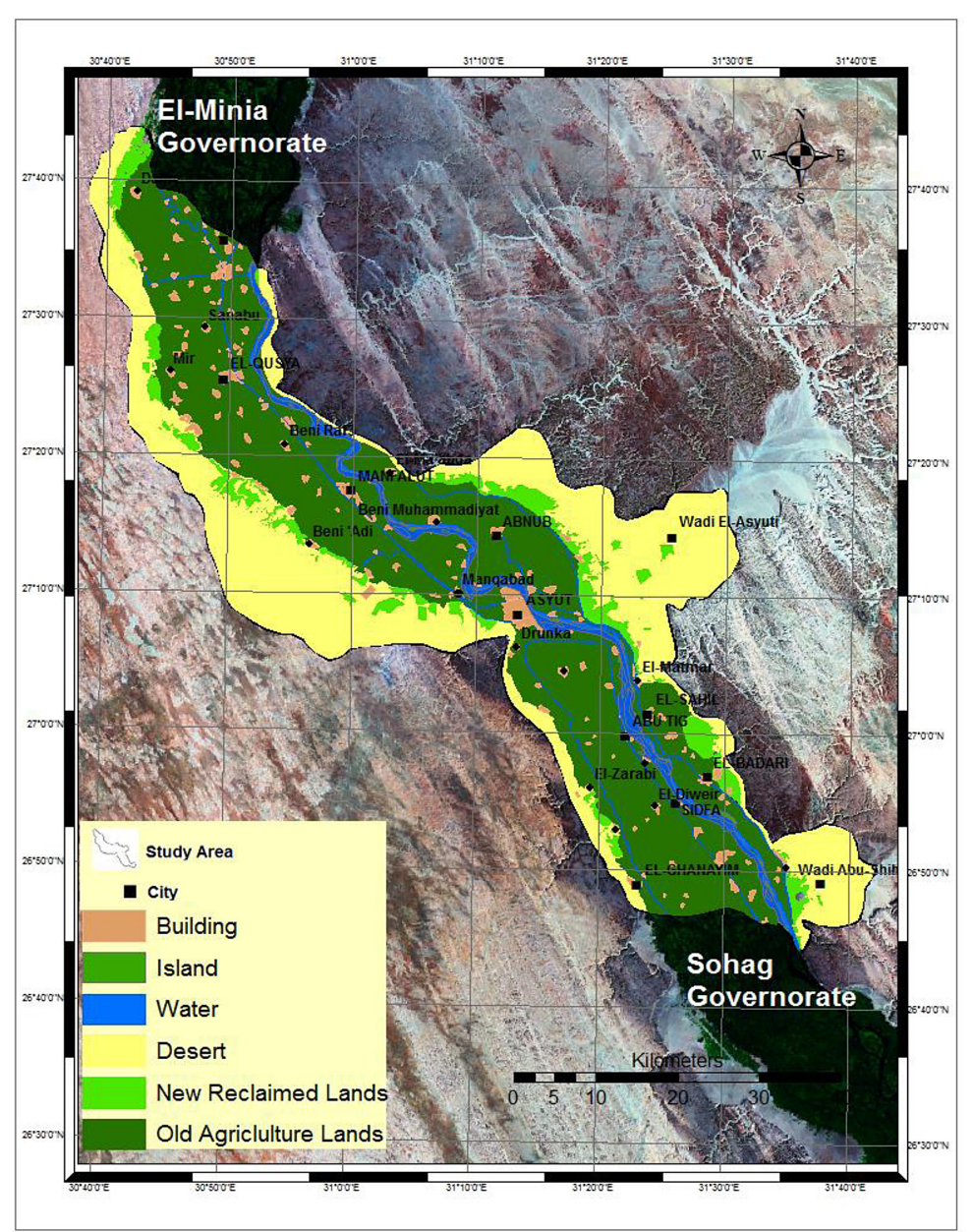

Figure 1. Land use map of he Assiut governorate created by ArcGIS (El Tahlawi et al., 2016). 


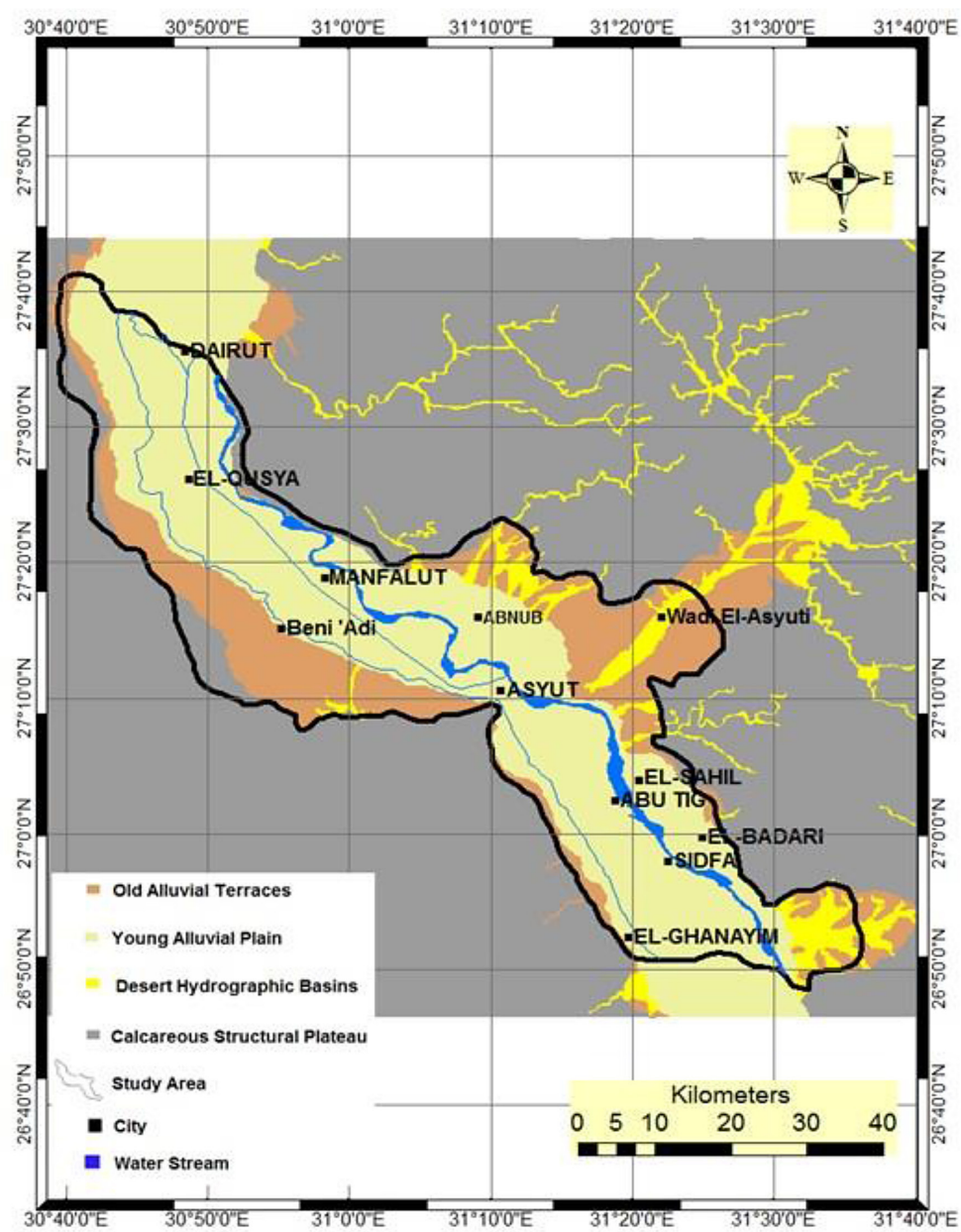

Figure 2. Geomorphic features of the Assiut region (Mansour and Philobbos, 1983).

\section{- Early Pleistocene Terraces}

There are some arguments about its name; Omara et al., (1969) and Shama, (1972) referred that these terraces are Plio-Pleistocene terraces while Said, (1990) defined them as they are of early Pleistocene age. Early Pleistocene terraces are made up of travertine conglomerate interbedded with clays, sandstones, and gravels.

- Late Pleistocene Terraces

The study area has a significant part of the late Pleistocene terraces which are formed of debris, loose deposits, limestone cobbles, and flint boulders. It is worth mentioning that large parts of these terraces are under reclamation (Aboul-Fetoh, 1994).

The calcareous structural plateau surrounds the Nile valley from two sides. This plateau is wide and created by hard Eocene limestone. The eastern plateau is marred by more faults than the western one. The erosion in the plateaux is controlled by lithological variations in the different rock types. The rock types include flinty limestone, chalky limestone, and marly limestone. The silicified and nummulitic limestones are always resistant to weathering (Figure. 2) (AboulFetoh, 1994), the eastern plateau includes wadies more than the western plateau. This may be due to the readily extended watershed area represented by the Red Sea Mountains that affect the hydrographic pattern on the Eastern Desert.

The desert hydrographic basins contain dry drainage lines directed into the Nile Basin, crossing the structural plains and the calcareous plateau. These drainage lines are defined as channel or wadi. These wadies direct towards the Nile, such as Wadi Drunka and Wadi El-Hagga Fatma in the western plateau, Wadi El-Assiuti, Wadi El-Ibrahimi and Wadi Abu Shih in the eastern plateau. Both the Eastern and Western plateau terminate Nile wards with precipitous, nearly parallel scarps that border the edge of the cultivated lands. At the foot of the limestone plateau and in the lower parts of the wadies, there are low hillocks of limestone plateau conglomerate 
as well as terraces which generally have various heights above the floor of the Nile valley. These sediments belong to the Plio-Pleistocene and Pleistocene (Ebrahim, 1997). This paper aims at studying the rock source which affects the chemistry of groundwater and determining the water type of Nile aquifer along the Assiut governorate. The collected data used can be classified into three categories: (a) physicochemical data; (b) hydrological data, and (c) geographic data. The groundwater hydrochemistry data include: electric conductivity, $\mathrm{pH}$, anions $\left(\mathrm{HCO}_{3}{ }^{-}, \mathrm{SO}_{4}{ }^{2-}\right.$, $\left.\mathrm{Cl}^{-}\right)$, cations $\left(\mathrm{Ca}^{2+}, \mathrm{Na}^{+}, \mathrm{Mg}^{2+}, \mathrm{K}^{+}\right), \mathrm{Fe}, \mathrm{Si}, \mathrm{Mn}$, TDS, Well depth, Water height, and Turbidity.

\section{TOPOGRAPHY}

Digital Elevation Model (DEM) map of the Assiut region was used to describe the topography and to obtain the slope map. The slope map declares that the general slope extends from south to north and from west to east. The mean elevation of the young alluvial plain is about $55 \mathrm{~m}$ above mean sea level. The surface elevation of the old alluvial terraces varies from $40 \mathrm{~m}$ to $75 \mathrm{~m}$. The calcareous structural plateau is divided into two parts; the western plateau has elevation ranges between $60 \mathrm{~m}$ in the north part and $200 \mathrm{~m}$ in the south part. For the eastern plateau, the elevation varies between $100 \mathrm{~m}$ in the north part and $300 \mathrm{~m}$ in the south part. The slope is crossed by a network of drainage streams system that goes from the higher slope to the lower (Figure 3).

\section{GEOLOGY}

Stratigraphically, Assiut is wholly covered with sedimentary rocks, as shown in Figure 4. The lithostratigraphic units will be explained in some details from the oldest unit to the latest one. The two main epochs that appear are Tertiary Epoch and Quaternary Epoch. The tertiary epoch includes the Eocene age in three aspects; lower, middle, and upper Eocene with the different groups and formations.

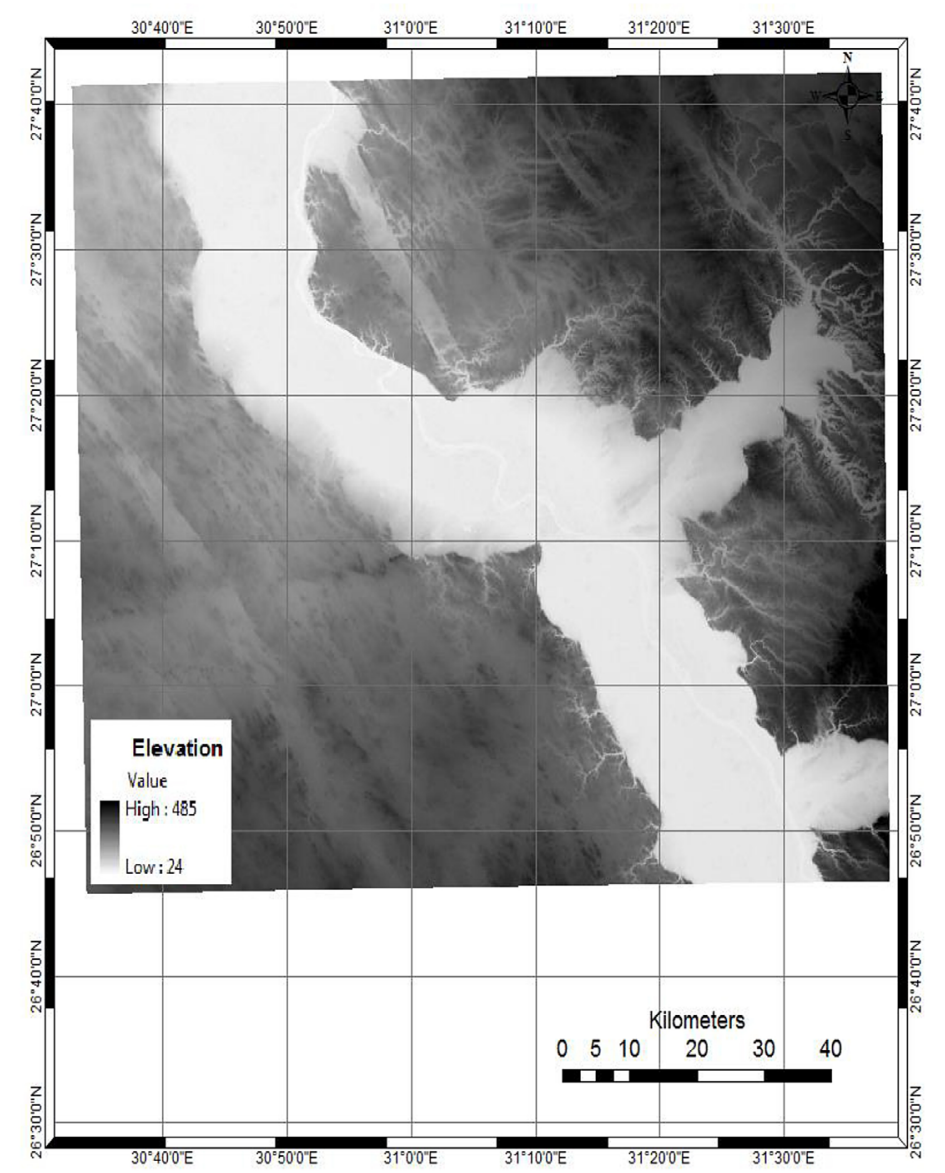

Figure 3. Digital Elevation Model (DEM) of Assiut Region (ASTER GDEM, 2011). 


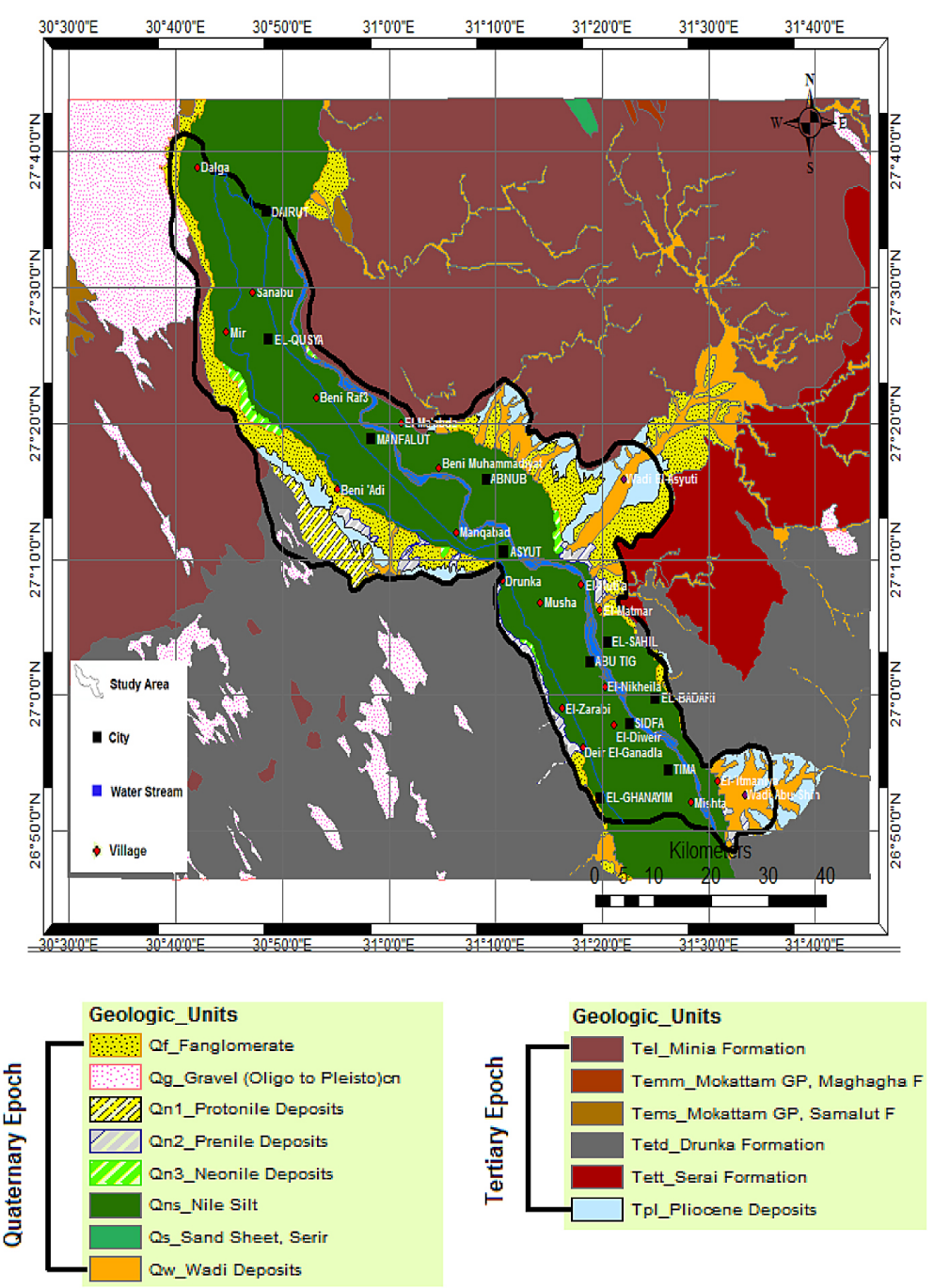

Figure 4. Geological map of Assiut region (CONOCO, 1987)

The main second epoch is quaternary epoch, which can be divided into 7 different deposits as the following:

- The gravel fills take place along the middle limestone plateau look like heaps and are composed of bedded gravel created by limestone and chert embedded in the silty matrix.

- The Protonile deposits are of Early Pleistocene age. The Protonile sediments consist of complex gravel, coarse sand and loamy materials. They are known as Idfu Formation which consists offlintand quartz with minor ingredients of igneous and metamorphic pebbles. They have red soil, which is probably the most distinctive characteristic of the sediments (Said, 1981).

- The Prenile deposits carried a lot of sediments to the Egyptian land, mainly sands. They belong to Middle Pleistocene. The Prenile sands were deposited on its large flood plains and delta. In general, its sediments are distinguished by being coarse, massive and thick. The graded sand-gravel unit of this period underlies the agricultural silt layer of the fertile land of Egypt (Said, 1981).

- The deposits of the Neonile are made up of silts and clays which are impossible to differentiate in aspect and construction from the deposits sedimented above the Egypt land by the modern Nile up to the very recent past (Bakheit, 1983). These sediments belong to Late Pleistocene age (Said, 1981).

- Wadi deposits - consist of coarse sand and sandy loam mixed with cobbles, gravels and rock fragments derived from the Eocene exposures. They take over the channels and tributaries of the desert wadies. These deposits vary in thickness from one locality to another, due to structural features. 
- Fanglomerate deposits mainly include alluvial fans and are composed of conglomerates and breccias.

- The Nile silt unconformably covers the sediments of the middle Pleistocene (Prenile). The Nile silt widely spreads through the whole area and varies in thickness from one place to another, with a mean value of about $9 \mathrm{~m}$. This silt layer is the main product of the annual flood of the river over the entire Nile basin. It is created by fine sands, dominated by quartz grains and some heavy minerals.

\section{METHODOLOGY}

The data collected include: electric conductivity (EC), $\mathrm{pH}$, anions $\left(\mathrm{HCO}_{3}^{-}, \mathrm{SO}_{4}^{2-}, \mathrm{Cl}^{-}\right)$, cations $\left(\mathrm{Ca}^{2+}, \mathrm{Na}^{+}, \mathrm{Mg}^{2+}, \mathrm{K}^{+}\right), \mathrm{Fe}, \mathrm{Mn}, \mathrm{Zn}, \mathrm{Cu}, \mathrm{Si}$, TDS, Well depth, Water height in each well, coordinates of wells, Landsat Satellite image, geological map and Digital Elevation Model (DEM) of the Assiut region. The anion-cation balance was used as one of the common methods of analysis reliability to discover any obvious conflicts in the groundwater analysis. Because the water is an electrically neutral solution, it can depend on this principle to make sure the accuracy of the analysis. The anioncation balance theory states that "the sum of cations in meq/L should equal the sum of the anions in meq/l". This balance is generally expressed as a percentage, as it is shown in the equation 1:

$$
\text { Balance }=\left(\sum C-\sum A\right) /\left(\sum C+\sum A\right) * 100
$$

where: $\Sigma C$ is the sum of cations,

$$
\sum A \text { is the sum of anions. }
$$

If the balance value is less than $5 \%$, the analysis is assumed to be good, but if it is much greater than $5 \%$, this means the analysis is inaccurate (Hounslow, 1995).

\section{Determination of water types}

Groundwater categorizes many water types based on its chemical analysis. The categorization is done throughout plot diagrams like the piper diagram. This plot was used to identify the water type (Hounslow, 1995). Piper diagram and rock source deduction were performed using Aquachem software package.

The Piper diagram consists of three different parts, i.e. two triangular parts and one diamond part. The diamond part was used to distinguish between various water types. This diagram can classify water to four essential types based on their position close to the four corners of the diamond. The water samples which are located in the upper part of the diamond are considered as high in $\mathrm{Na}^{+}, \mathrm{Ca}^{2+}, \mathrm{HCO}_{3}^{-}$and $\mathrm{SO}_{4}^{2-}$. The water samples which are plotted in the lower opposite corner are mainly composed of $\mathrm{Mg}^{2+}$ and $\mathrm{Cl}^{-}$. The water samples falling near the right corner of the diamond may be considered as $\mathrm{Na}^{+}, \mathrm{Ca}^{2+}$, and $\mathrm{Cl}^{-}$ type. On the other hand, the samples lying nearby the left corner are rich in $\mathrm{Mg}^{2+}, \mathrm{HCO}_{3}$-and $\mathrm{SO}_{4}{ }^{2-}$ (Hounslow, 1995). These four different parts are demonstrated in Figure 5.

\section{Criteria of rock-source deduction}

The rock source deduction process is conducted using different essential ratios, representing the criteria of the rock-source deduction process.

The aim of this procedure can be summarized as probability identifying of a water analysis source. Source-rock deduction is considered a useful tool, regardless of whether the water source was known or unknown. If the origin of the water analysis is known, then the source-rock deduction will be used for confirmation, but if it is unknown, the source-rock deduction is considered as an important exploration step. This method is based on a basic mass balance process involving the data of water quality (Hounslow, 1995). In this paper, different essential ratios representing the criteria of rock-source deduction were used (Table 1).

The groundwater quality is greatly altered by the effect of weathering and anthropogenic contributions. Therefore, Gibbs plot is used to know and distinguish the impact of rock-water interaction, evaporation and precipitation on water chemistry. The Gibbs diagram is commonly used to set up the correlation between water composition and aquifer lithological characteristics (Gibbs, 1970). It includes three different areas which are precipitation dominance, evaporation dominance, and rockwater interaction dominance (Figure 6) (Barick, and Ratha, 2014). Equations (2) and (3) point up Gibbs ratio for anions and cations as follows:

$$
\text { Gibbs ratio I (for anions) }=\frac{\mathrm{Cl}^{-}}{\mathrm{Cl}^{-+\mathrm{HCO}_{3}^{-}}}
$$

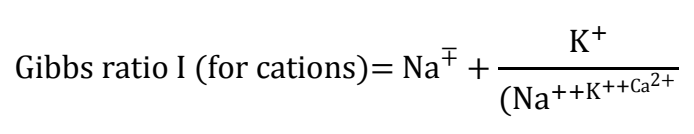




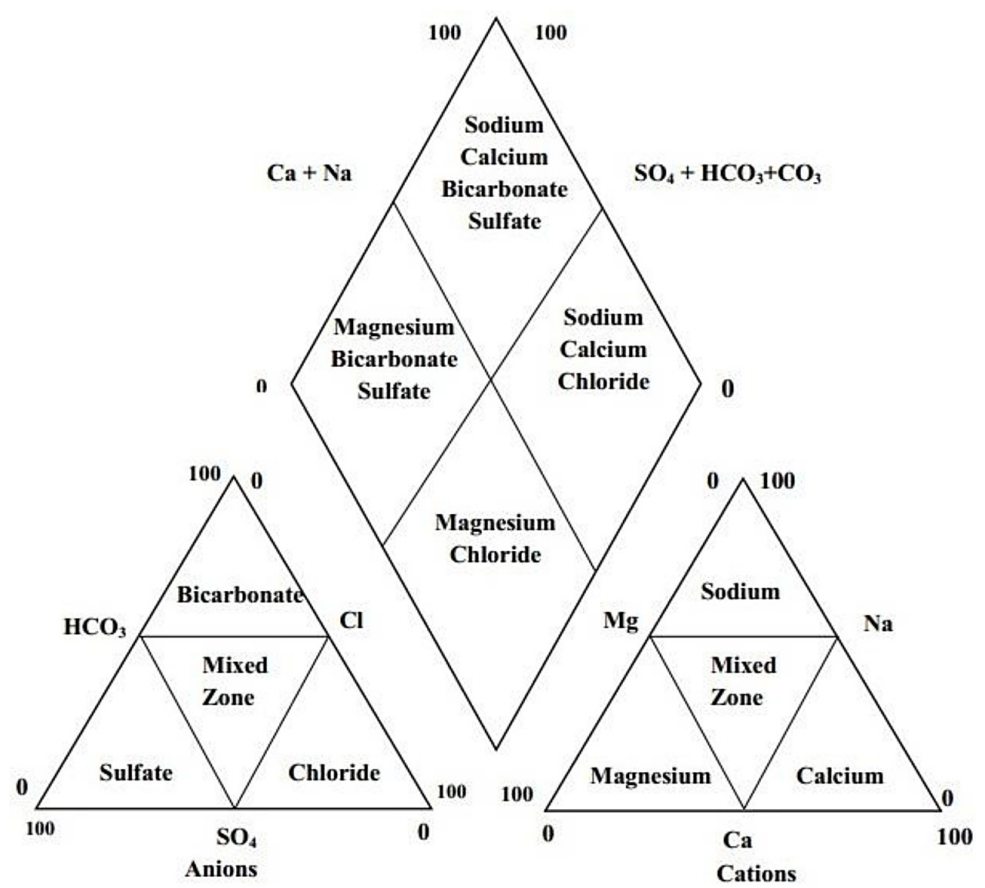

Figure 5. Different water typed in the diamond portion of piper diagram.

Table 1: Summary of used parameters for rock-source deduction (Hounslow, 1995).

\begin{tabular}{|c|c|c|}
\hline Parameter & Attention Value & Conclusion \\
\hline \multirow{2}{*}{$\frac{(\mathrm{Na}+\mathrm{K}-\mathrm{Cl})}{(\mathrm{Na}+\mathrm{K}-\mathrm{Cl}+\mathrm{Ca})}$} & $>0.2$ and $<0.8$ & Plagioclase weathering possible \\
\hline & $<0.2$ or $>0.8$ & Plagioclase weathering unlikely \\
\hline \multirow{5}{*}{$\frac{\mathrm{Na}}{\mathrm{Na}+\mathrm{Cl}}$} & $>0.5$ & Sodium source other than halite - albite, ion exchange \\
\hline & 0.5 & Halite solution \\
\hline & $<0.5$, TDS $>500$ & Reverse Softening, seawater \\
\hline & $<0.5$, TDS $<500$ and $>50$ & Analysis Error \\
\hline & $<0.5$, TDS $<50$ & Rainwater \\
\hline \multirow{4}{*}{$\frac{\mathrm{Ca}}{\mathrm{Ca}+\mathrm{SO}_{4}}$} & 0.5 & Gypsum dissolution \\
\hline & $<0.5$, and $\mathrm{pH}<5.5$ & Pyrite oxidation \\
\hline & $<0.5$, and $\mathrm{pH}$ neutral & Calcium removal - ion exchange or calcite precipitation \\
\hline & $>0.5$ & Calcium source other than gypsum - carbonate or silicates \\
\hline \multirow{2}{*}{ TDS } & $>500$ & Carbonate weathering or brine or seawater \\
\hline & $<500$ & Silicate weathering \\
\hline$\frac{M g^{2+}}{C a^{2+}+M g^{2+}}$ & $\begin{array}{l}\mathrm{HCO}_{3} / \mathrm{SiO}_{2}>10 \\
=5 \\
<5 \\
>5 \\
\mathrm{HCO}_{3} / \mathrm{SiO}_{2}<5 \\
>5 \\
<5\end{array}$ & $\begin{array}{l}\text { Carbonate weathering } \\
\text { Dolomite weathering } \\
\text { Limestone-Dolomite weathering } \\
\text { Dolomite dissolution, Calcite precipitation or sea water } \\
\text { Silicate weathering } \\
\text { Ferromagnesian minerals } \\
\text { Granitic weathering }\end{array}$ \\
\hline \multirow{3}{*}{$\frac{\mathrm{Cl}}{\text { Sum Anions }}$} & $>0.8$ and TDS $>500$ & Seawater or brine or evaporates \\
\hline & $>0.8$ and TDS $<100$ & Rainwater \\
\hline & $<0.8$ & Rock weathering \\
\hline
\end{tabular}




\section{RESULTS AND DISCUSSIONS}

The results can be concluded in terms of two main objectives: Determining groundwater type and Rock Source Deduction.

\section{Determining groundwater type}

The samples of groundwater wells were plotted on the Piper-trilinear diagram to conclude hydrochemical facies in order to understand the water type. The water facies mirrors the signing up of two things which are natural water recharge and water-soil/rock interaction. The piper diagram of the groundwater samples which were taken in 2015 is shown in Figure. 7.
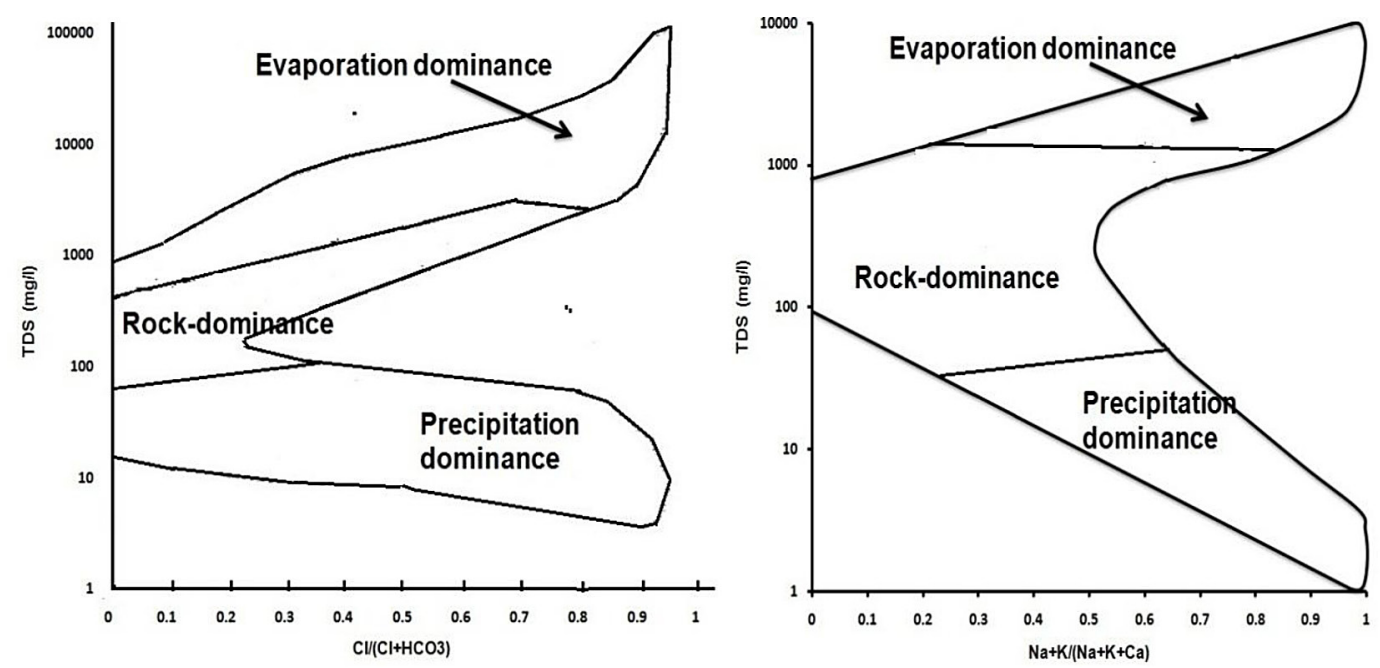

Figure 6. Gibbs diagram for anions and cations (Barick, and Ratha, 2014).

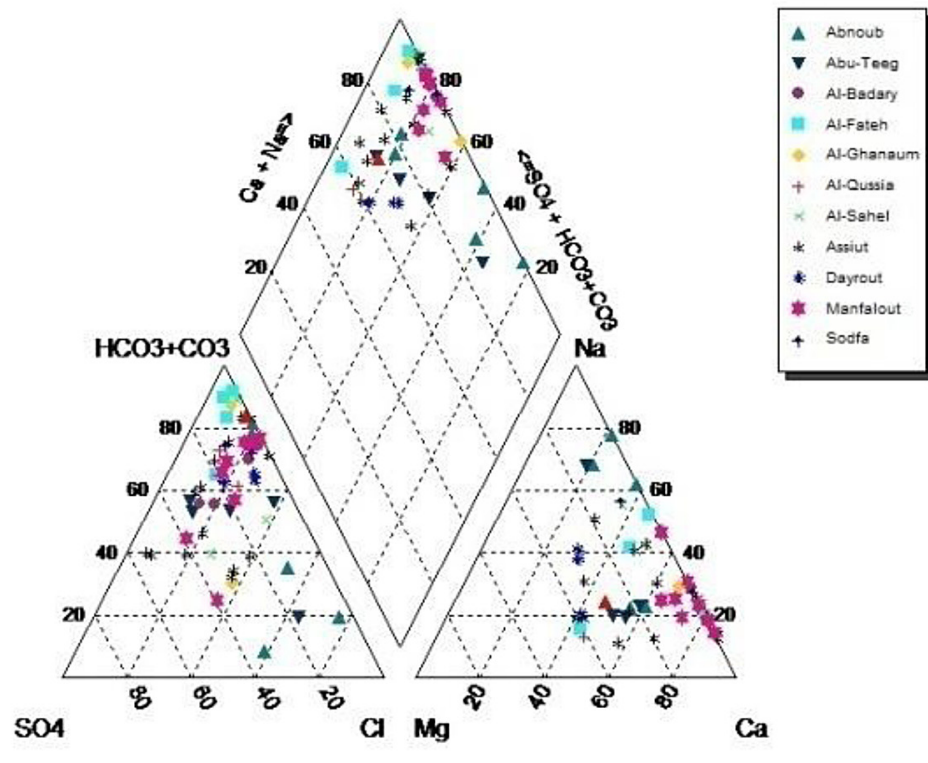

Figure 7. Piper Diagram of groundwater wells in 2015 
addition, the early Pleistocene terraces are made up of travertine, which is a form of limestone; hence, the interaction between water and travertine increases the chance of dissolving more calcium and bicarbonate in the Nile aquifer. The late Pleistocene terraces are formed of debris, loose deposits, limestone cobbles, and flint boulders, in addition to the large parts of these terraces are under reclamation; thus, the same result will be affirmed because the possibility of water-Pleistocene terraces interaction can still take place.

Limestone is composed generally of calcite minerals. The solubility of calcite is governed by the total existing amount of carbon dioxide and hydrogen ion, as these amount are high, the dissolving of calcite will also be high. The carbon dioxide existing in the soil can leak into the groundwater and interact with clay minerals and sandstone to liberate cations like $\mathrm{Ca}$ and $\mathrm{Mg}$. With regard to the samples which distinguished by $\mathrm{Ca}$ and $\mathrm{Na}$ dominant, this dominance can attributed to weathering which has occurred by the sodium and potassium bearing minerals.

Along with water type determination, rock source deduction was done. Gibbs plot points up that nearly all wells drop in the water-rock interaction field and the minority wells fall on the evaporation zone (Figure. 8 a, Figure. 8 b), accordingly, the rock dominance field is the common zone in this area, which means that the interaction between rock and water chemistries has occurred.

\section{Results of rock-source deduction}

This process aims at identifying the source of water analysis whether it is due to aquifer mineralogy or reaction. In this paper, different essential ratio representing the criteria of rock-source deduction was used.

These criteria mainly depend upon many ionic comparisons (Table 1). On the basis of those ionic comparisons, Table 2 was prepared to summarize the results of rock-source deduction. The first ratio of $\mathrm{Na}+\mathrm{K}-\mathrm{Cl}$ to $\mathrm{Na}+\mathrm{K}+\mathrm{Ca}-\mathrm{Cl}$ is less than 0.2 for 39 samples, which equals to $71 \%$ of all samples, indicating plagioclase weathering is unlikely. Moreover, 16 samples have the values more than $0.2(29 \%)$, which suggests that the plagioclase weathering is possible for such samples. The results of sodium to sodium plus chloride ratio show that 42 samples $(76.5 \%$ of all samples) are higher than 0.5 ; this confirms that sodium source is other than halite-albite, ion exchange. With regard to the ratio between calcium and calcium plus sulfate, the results of all samples are more than 0.5 , proving that calcium source is other than gypsum-carbonate or silicate.

According to TDS value, the obtained results reveal that 43 samples ( $78 \%$ of all samples) are greater than 500 , indicating carbonate weathering is predominant; however, 12 samples $(22 \%$ of all samples) are less than 500, corresponding to silicate weathering.

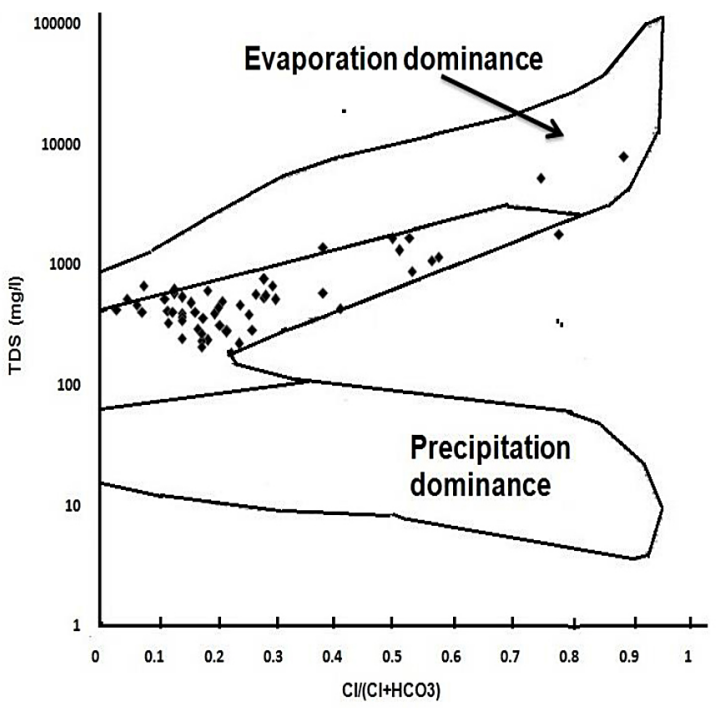

(a) Gibbs diagram of cations

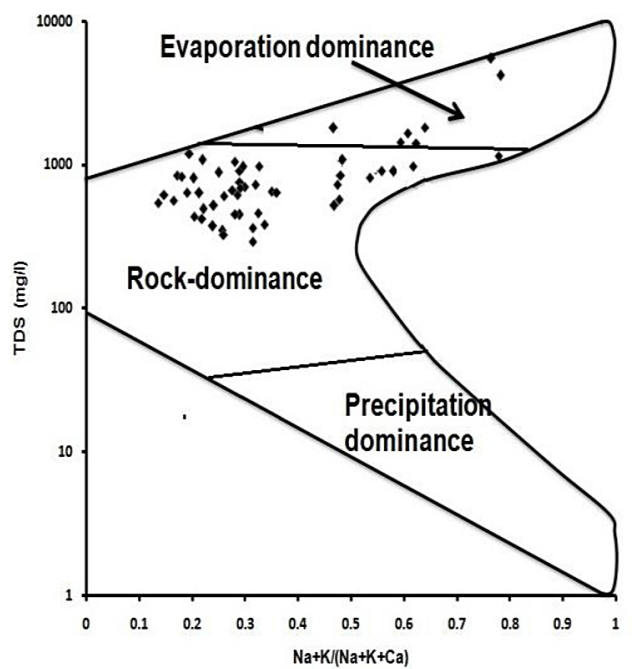

(b) Gibbs diagram of anions

Figure 8. Gibbs diagram showing the controlling mechanism of groundwater quality

(a) Gibbs diagram of cations (b) Gibbs diagram of anions 
One of the most important results that have been obtained (Table 2) is the ratio of magnesium to calcium plus magnesium, where 49 samples which is equivalent to $89 \%$ of all samples - are lower than 0.5 , while bicarbonate to silica ratio is higher than 10 , this result indicates that rocksource is limestone-dolomite weathering. In turn, 6 samples have the ratios of magnesium to magnesium plus calcium less than 0.5 but the bicarbonate to silica ratio is less than 5 , so these samples belong to granitic weathering as a rocksource. Finally, the ratio of chloride to the sum of anions is less than 0.8 for all samples, concluding rock weathering has dominated. On the basis of Table 2, piper diagram (Figure. 7) and Gibbs diagram (Figure. 8), it can be concluded that the main rock-source for the groundwater of the Nile aquifer is the limestone resulting from carbonate weathering of the calcareous structural plateau.

\section{CONCLUSIONS}

The iron and manganese ion concentrations are high in all the data taken in 2015. This result is attributed to solution of those elements in water from surrounding rocks and soil. Moreover, there are high concentrations of $\mathrm{HCO}_{3}^{-}$in most areas, exceeding the WHO standard limits. The high levels of carbonates in nearly all wells result from the calcareous structural plateau. The water type of most samples is $\mathrm{Na}-\mathrm{Ca}-\mathrm{HCO}_{3}-\mathrm{SO}_{4}$ facies and $\mathrm{Na}-\mathrm{Ca}-\mathrm{Cl}$ facies, according to the piper diagram. This confirms the effect of the calcareous structural plateau on the groundwater chemistry. As a consequence of the interaction between the groundwater and the limestone found in the calcareous plateau, the dominant water type in the Nile aquifer along Assiut governorate is sodium-calcium-bicarbonate-sulfate. In addition,

Table 2: Summary of rock-source deduction results

\begin{tabular}{|c|c|c|c|c|}
\hline Parameter & Attention Value & Conclusion & $\begin{array}{l}\text { No of } \\
\text { sample } \\
\text { s }\end{array}$ & $\%$ \\
\hline \multirow{2}{*}{$\frac{(\mathrm{Na}+\mathrm{K}-\mathrm{Cl})}{(\mathrm{Na}+\mathrm{K}-\mathrm{Cl}+\mathrm{Ca})}$} & $>0.2$ and $<0.8$ & Plagioclase weathering possible & 16 & 29 \\
\hline & $<0.2$ or $>0.8$ & Plagioclase weathering unlikely & 39 & 71 \\
\hline \multirow{5}{*}{$\frac{\mathrm{Na}}{\mathrm{Na}+\mathrm{Cl}}$} & $>0.5$ & Sodium source other than halite - albite, ion exchange & 42 & 76.5 \\
\hline & 0.5 & Halite solution & & \\
\hline & $<0.5$, TDS $>500$ & Reverse Softening, seawater & 9 & 16 \\
\hline & $<0.5$, TDS $<500$ and $>50$ & Analysis Error & 3 & 5.5 \\
\hline & $<0.5$, TDS $<50$ & Rainwater & 1 & 2 \\
\hline \multirow{4}{*}{$\frac{\mathrm{Ca}}{\mathrm{a}+\mathrm{SO}_{4}}$} & 0.5 & Gypsum dissolution & & \\
\hline & $<0.5$, and $\mathrm{pH}<5.5$ & Pyrite oxidation & & \\
\hline & $<0.5$, and $\mathrm{pH}$ neutral & Calcium removal - ion exchange or calcite precipitation & & \\
\hline & $>0.5$ & $\begin{array}{l}\text { Calcium source other than gypsum - carbonate or } \\
\text { silicates }\end{array}$ & 55 & 100 \\
\hline \multirow{2}{*}{ TDS } & $>500$ & Carbonate weathering or brine or seawater & 43 & 78 \\
\hline & $<500$ & Silicate weathering & 12 & 22 \\
\hline$\frac{M g^{2+}}{C a^{2+}+M g^{2+}}$ & $\begin{array}{l}\mathrm{HCO}_{3} / \mathrm{SiO}_{2}>10 \\
=0.5 \\
<0.5 \\
>0.5 \\
\mathrm{HCO}_{3} / \mathrm{SiO}_{2}<5 \\
>0.5 \\
<0.5\end{array}$ & $\begin{array}{l}\text { Carbonate weathering: } \\
\text { Dolomite weathering } \\
\text { Limestone-Dolomite weathering } \\
\text { Dolomite dissolution, Calcite precipitation or sea } \\
\text { water } \\
\text { Silicate weathering: } \\
\quad \text { Ferromagnesian minerals } \\
\text { Granitic weathering }\end{array}$ & 49 & 11 \\
\hline \multirow{3}{*}{$\frac{\mathrm{Cl}}{\text { Sum Anions }}$} & $>0.8$ and TDS $>500$ & Seawater or brine or evaporates & & \\
\hline & $>0.8$ and TDS $<100$ & Rainwater & & \\
\hline & $<0.8$ & Rock weathering & 55 & 100 \\
\hline
\end{tabular}


the early Pleistocene terraces contain travertine, also a form of limestone, which causes an interaction between water and travertine, increasing the chances of more dissolved calcium and bicarbonate in the Nile aquifer. The results point up that nearly all wells drop in the water-rock interaction field in Gibbs diagram, while the minority samples fall in the evaporation zone. Hence, the rock dominance field is the common zone in this area, this means that the interaction between rock and water chemistries has occurred. Out of all samples, $71 \%$ indicate that plagioclase weathering is unlikely, while $29 \%$ show that the plagioclase weathering is possible. Additionally, $78 \%$ of all samples indicate that carbonate weathering is predominant, whereas $22 \%$ point at silicate weathering. Finally, $89 \%$ of all entire samples indicate that rock-source is limestone-dolomite weathering, whereas $11 \%$ of samples refer to granitic weathering as the rock-source.

\section{Acknowledgements}

The authors thankfully acknowledge the Department of Geology, Faculty of Sciences, Assiut University for providing useful support for this paper. As well as the authors would like to extend their sincere thanks to water and soil fertility laboratory in Assiut for conducting chemical analyzes of groundwater samples.

\section{REFERENCES}

1. Aboul-Fetoh, A.E., (1994). Geoelectrical and hydrogeologic studies on the quaternary aquifer in the Nile valley in Assiut and Sohag governorates, Egypt", Ph.D. thesis, Ain shams university, Egypt.

2. ALDAR, CH2M HILL, Spain, 2011. Study of environmental and social impact assessment framework (ESIAF) of Assiut \& Sohag governorates, executive Summary. Egypt, 82 pp.

3. ASTER GDEM, 2011. ASTER Global Digital Elevation Model. Ver. 2.0, link: http://www.jspacesystems.or.jp/ersdac/GDEM/E/4.html.

4. Bahrgava, D.S., Killender, D.J., 1988. The technology of water resources in Industries. A rational approach. Jr. Ind. Wat. Works Assn., 20(1), 107-112.

5. Bakheit, A.A., 1983. Geophysical and geological studies on the entrance of Wadi El-Assuity, eastern desert", M.Sc thesis, Assuit university, Egypt.
6. Barick, S.R., Ratha, B.K., 2014. Hydro-chemical analysis and evaluation of groundwater quality of Hial area, Bolangir district, Odisha, India. Journal of Geosciences and Geomatics, 2(5A), 22-28.

7. CONOCO, 1987. Geological map of Egypt (Scale 1: 500000). Sheet: NG $36 \mathrm{NW}$ Assiut, published by EGPC and CONOCO, Cairo, Egypt.

8. Dawoud, M.A., Ewea, H.A., 2009. Sustainable development via optimal integration of surface and groundwater in arid environment: Nile river quaternary aquifer case study. The International Conference on Water Conversation in Arid Regions, pp. 12-14.

9. Ebrahim, M.O., 1997. Application of surface geoelecrtical methods for the detection of groundwater contamination in the area northwest of Assiut city (El Madabegh). M.sc. thesis, Geology Dept. Faculty of science, Assiut university, Egypt.

10. El-Tahlawi, M.R., AboEl-Kassem, M., Baghdadi, G.Y., Saleem, H.A., 2016. Assessment of groundwater vulnerability - a case study. International Journal of Advanced Remote Sensing and GIS. Cloud Publications. 5(2), 1561-1579.

11. Freeze, R.A., Cherry, J.A., 1979. Groundwater. Prentice Hall, Englewood, Cliffs.

12. Gibbs, R.J., 1970. Mechanisms controlling world water chemistry. American Association for the Advancement of Science.170(3962), 1088-1090.

13. Hounslow, A.W., 1995. Water quality data: analysis and interpretation. CRC Press, $416 \mathrm{pp}$.

14. Mansour, H.H., Philobbos, E.R., 1983. Lithostratigraphic classification of the surface eocene carbonates of the Nile valley, Egypt: a review. Bull. Fac. Sci. Assiut Uni. 12(2), 129-151.

15. Omara,S.,El-Tahlawi,M.R.,Hafez,H.,1969.Microfacies of lower eocene limestones in the environs of Assiut. 6th Arab Science Cong. Damascus, part 4:B.

16. Raghunath, H.M., 1987. Groundwater. Wiley Eastern Ltd, New Delhi, 563 p.

17. Said, R., 1981. The Geological Evolution of the River Nile. Springer, New York, 151 pp.

18. Said, R., 1990. The geology of Egypt. S.A., Balkema, Rotterdam, Brookfield, 731p.

19. Shama, K.M., 1972. The geology of the area lying between the latitude of Manfalut and Deirut in the eastern side of the Nile valley. M.Sc. Thesis, Dept. of geology, Assiut university.

20. Singh, C.K., Shashtri, S., Mukherjee, S., 2011. Integrating multivariate statistical analysis with GIS for geochemical assessment of groundwater quality in Shiwaliks of Punjab, India. Environ Earth Sci 62(7), 1387-1405. 